\title{
Supplemental fat for dairy calves during mild cold stress
}

\author{
N. B. Litherland, ${ }^{\star 1}$ D. N. L. Da Silva, ${ }^{\star}$ R. J. LaBerge, ${ }^{\star}$ J. Schefers, $†$ and A. Kertzł \\ ${ }^{*}$ Department of Animal Science, University of Minnesota, St. Paul 55108 \\ †College of Veterinary Medicine, University of Minnesota, St. Paul 55108 \\ ¥ANDHIL LLC, St. Louis, MO 63122
}

\section{ABSTRACT}

Eighty-one Holstein and Holstein-cross dairy calves fed calf milk replacer (CMR) were used to determine response to increasing amounts of supplemental fat during mild cold stress. Calves $(\mathrm{n}=27)$ were randomly assigned to 1 of 3 treatments: (1) low fat [LF; $28 \%$ crude protein: $15 \%$ fat milk replacer (28:15 MR)]; (2) medium fat [MF; $28: 15 \mathrm{MR}+113 \mathrm{~g} / \mathrm{d}$ of commercial fat supplement (FS)]; (3) high fat (HF; 28:15 MR + $227 \mathrm{~g} / \mathrm{d}$ of FS). The MF and HF calves received FS from d 2 to 21 , and all calves were fed LF from d 22 to 49 . The CMR was fed at $1.4 \%$ of birth body weight (BBW) from d 1 to 10 , at $1.8 \%$ of BBW from d 11 to 42 , and at $0.9 \%$ of BBW from d 43 to 49 . Calves were weaned on d 49 and remained in hutches until d 56. The CMR was reconstituted to $13 \%$ solids. Calves were fed a commercial starter grain $(19.2 \%$ crude protein on a dry matter basis) ad libitum and offered warm water after CMR feeding. Calves were fed CMR twice daily at 0630 and $1730 \mathrm{~h}$ in hutches bedded with straw. Starter intake, CMR intake, and ambient temperature were measured daily, and body weight (BW), hip height, and body length were measured weekly. Data were analyzed using PROC MIXED in SAS (SAS Institute Inc., Cary, NC) as a randomized design with linear and quadratic contrasts. Calf BBW averaged $42.0 \pm 1.0$ $\mathrm{kg}$, total serum protein averaged $5.8 \pm 0.1 \mathrm{mg} / \mathrm{dL}$, and birth ambient temperature averaged $5.0 \pm 1.1^{\circ} \mathrm{C}$. Feeding FS increased metabolizable energy intake $\left(\mathrm{ME}_{\mathrm{I}}\right)$ over maintenance but decreased efficiency of conversion of BW gain: $\mathrm{ME}_{\mathrm{I}}$. Starter intake by $\mathrm{LF}$ calves was greatest until the beginning of weaning, after which starter intake was similar among treatments. Because of higher starter intake, total $\mathrm{ME}_{\mathrm{I}}$ was similar among treatments. Feed efficiency through d 49 was greater for calves fed MF and HF. Average daily gain during fat supplementation was greater for MF and HF than for LF. Lack of increase in BW gain and feed efficiency

Received April 19, 2013

Accepted December 22, 2013

${ }^{1}$ Corresponding author: lithe003@umn.edu between MF and HF treatments indicated that HF did not result in advantages over MF. Supplementing fat to preweaned calves fed CMR increased BW gain and decreased starter intake through d 21 which had carryover effects on starter intake on d 49 and reduced hip height and tended to reduced withers height and body length by $\mathrm{d} 56$. The addition of supplemental fat to LF, during mild cold stress, may result in a suboptimal ratio of crude protein to metabolizable energy in the CMR.

Key words: preweaned dairy calf, milk replacer, supplemental fat, cold stress

\section{INTRODUCTION}

One of the most commonly experienced stressors in livestock is caused by fluctuations in environmental temperature that extend beyond the thermoneutral zone. The reported lower critical temperature (LCT) for a newborn dairy calf ranges from $13^{\circ} \mathrm{C}$ (Curtis, 1974) to $8^{\circ} \mathrm{C}$ (Young, 1981). As the temperature falls below the calf's LCT, a calf needs more dietary energy to maintain body temperature (Curtis, 1974; Young, 1981; NRC, 2001). If calves are fed the same amount of milk as under moderate environmental conditions, less energy will be available to support growth (Khan et al., 2011). Limited data are available to evaluate the effect of supplemental fat for preweaned calves during cold stress. Supplementing whole milk or milk replacer with $113 \mathrm{~g} / \mathrm{d}$ of supplemental fat increased BW gain during the first month of life (Jaster et al., 1990); however, those authors did not collect subsequent measurements after the first month of age. Additionally, research has demonstrated that additional fat added to milk replacer boosts daily gains during cold weather (Jaster et al., 1992). During the last 2 wk of their 6 -wk trial, however, Jaster et al. (1992) observed no response or a negative carryover response after fat was discontinued, indicating that the abrupt change in milk replacer fat supplement or the shift in CP:ME had a negative effect on calf growth. Numerous studies have investigated effects of varying the FA profile of calf milk replacer (Jenkins et al., 1985; Piot et al., 1999; Hill et al., 2007; Mills 
et al., 2010); however, few studies have been designed to specifically target the amount of supplemental fat fed during the early preweaned phase. Increasing rates of milk replacer feeding have been shown to increase growth rates, reduce starter intake, and delay rumen development (Bar-Peled et al., 1997; Jasper and Weary, 2002; Terré and Bach, 2007). Increasing the amount of dietary fat has previously been reported to increase body fat gain and reduce protein deposition (Tikofsky et al., 2001; Bascom et al., 2007; van den Borne et al., 2007). Cold-stressed calves, however, might benefit from supplemental fat by sparing glucose and AA, which are used for thermoregulation when calves are managed in conditions below the thermal neutral zone. Milk fat concentration of maternal transition milk, as well as whole milk, indicates that calves are naturally programmed to consume high-fat milk during the early days of life (Bernal-Santos et al., 2003). Supplemental fat might reduce amount of AA catabolized for energy, resulting in a greater proportion of dietary AA available for lean tissue growth. To test this hypothesis, milk replacer must be fed that provides sufficient amounts of protein to meet the AA requirements of preweaned calves for growth and maintenance (Donnelly and Hutton, 1976; Bartlett et al., 2006). Enhanced early nutrition capitalizes on growth efficiency early in life being driven more by increasing protein and lactose intake than by increasing fat intake (Tikofsky et al., 2001; Hill et al., 2008). Supplemental fat might also spare energy that can be used for functions beyond growth, including immune function (Nonnecke et al., 2003). Khan et al. (2007) found that providing calves a large amount of milk early in life and then reducing milk intake before weaning (step-down method) caused a surge in solid feed intake. Removing supplemental fat from milk replacer could be considered an alternative approach to inducing a similar step-down effect on starter intake without altering the amount of milk replacer fed. Supplemental fat might be optimally positioned early in the first $3 \mathrm{wk}$ when nutrient intake from starter is expected to be low. Questions remain regarding the amount of supplemental fat to optimize calf nutrient intake for calf growth and health during cold stress. The objectives of this experiment were (1) to determine if increasing fat intake during the first $21 \mathrm{~d}$ of the preweaned phase alters energy intake over maintenance, efficiency of growth, and voluntary starter intake, and (2) to determine if response in calf performance is altered by supplemental fat amount. We hypothesized that supplemental fat would decrease starter intake during the first month of the preweaned phase but energy available for growth would be greater, resulting in increased calf growth.

\section{MATERIALS AND METHODS}

\section{Animals}

The experimental protocol was reviewed and approved by the University of Minnesota Institutional Animal Care and Use Committee. Eighty-one $(\mathrm{n}=27$ per treatment) Holstein and Holstein-cross calves born at the University of Minnesota Dairy Teaching and Research Center (St. Paul, MN) were enrolled in the study. At birth, calves were removed from their dams and identified with a unique ear tag. Then, birth body weight (BBW) was recorded, navels were dipped, and each calf remained in a heated indoor pen for the first $48 \mathrm{~h}$ after birth. Calves received approximately $1.9 \mathrm{~L}$ of colostrum at each of the first 3 feedings (within $2 \mathrm{~h}$ after birth and again approximately 12 and $24 \mathrm{~h}$ after the first feeding) and were trained to drink calf milk replacer (CMR) from buckets during the first $4 \mathrm{~d}$ of life. A blood sample was collected via jugular venipuncture into evacuated serum collection tubes (SST Vacutainer, Becton Dickinson, Franklin Lakes, NJ) 24 h after birth and centrifuged at $2,000 \times g$ for $20 \mathrm{~min}$. Serum was separated and analyzed for total serum protein concentration using a refractometer (Rhino VET360, Reichert, Depew, NY); serum total protein averaged $5.8 \pm 0.1$ $\mathrm{mg} / \mathrm{dL}$. Serum hematocrit was not measured. Each calf was placed in a calf hutch (PolyDome, Litchfield, MN) bedded with wheat straw.

\section{Assignments to Treatments and Feeding}

Experimental design was a randomized design with 3 treatments. Calves were assigned to 1 of 3 treatments: (1) low fat $[\mathbf{L F} ; 28 \% \mathrm{CP}, 15 \%$ fat milk replacer $(\mathbf{2 8 : 1 5}$ MR)]; (2) medium fat [MF; 28:15 MR + $113 \mathrm{~g} / \mathrm{d}$ of commercial fat supplement (FS)]; (3) high fat (HF; 28:15 MR $+227 \mathrm{~g} / \mathrm{d}$ of FS). The MF and HF calves received FS from d 2 to 21 , and all calves were fed LF from d 22 to 49 . Calf milk replacer was reconstituted to $13 \%$ solids and fed at $1.4 \%$ of BBW from $\mathrm{d} 1$ to 10 , at $1.8 \%$ of BBW from d 11 to 42 , and at $0.9 \%$ of BBW from d 43 to 49 . Calves were fed CMR twice daily at 0630 and $1730 \mathrm{~h}$ in hutches. Calves were weaned on d 49 and remained in hutches until d 56. Calves were fed a commercial texturized starter grain ad libitum (Table 1). Starter refusals were recorded daily and refusals of CMR were recorded at each feeding. To provide ad libitum drinking water, approximately 4 to $10 \mathrm{~L}$ of drinking water was provided daily depending on calf age. Calves were bedded with straw on Tuesday and Saturday of every week. Quality of calf bedding was evaluated 3 times weekly (Monday, Wednesday, and Friday) using nesting scores when calves were lying down in hutches 
Table 1. Nutrient composition of milk replacer (28\% CP, $15 \%$ fat), fat supplement, and starter grain fed to preweaned calves during mild cold stress

\begin{tabular}{lccc}
\hline Item & $\begin{array}{c}\text { Milk replacer } \\
(28: 15)\end{array}$ & $\begin{array}{c}\text { Fat } \\
\text { supplement }\end{array}$ & $\begin{array}{c}\text { Starter } \\
\text { grain }\end{array}$ \\
\hline CP, \% & 30.9 & 7.7 & 21.8 \\
Ether extract, \% & 15.7 & 57.4 & 3.8 \\
ME, Mcal/kg & 4.6 & 6.5 & 2.8 \\
Amylase-treated NDF, \% & $<0.01$ & $<0.01$ & 30.1 \\
Ash, \% & 8.3 & 4.2 & 4.23 \\
Calcium, \% & 1.0 & 0.3 & 1.0 \\
Phosphorous, \% & 0.8 & 0.3 & 0.5 \\
Magnesium, \% & 0.12 & 0.04 & 0.3 \\
Potassium, \% & 1.80 & 0.92 & 1.3 \\
Sulfur, \% & 0.40 & 0.08 & 0.3 \\
Sodium, \% & 0.65 & 0.35 & 0.2 \\
Manganese, mg/kg & 22 & 1.0 & 145.0 \\
Zinc, mg/kg & 118 & 9.0 & 130.0 \\
Copper, mg/kg & 15 & 2.0 & 31.0 \\
Iron, mg/kg & 162 & 19 & 369.0 \\
Molybdenum, mg/kg & 0.63 & 0.16 & 2.1 \\
\hline
\end{tabular}

$(1=$ calf legs are completely nestled into straw; $2=$ calf legs are partially nestled into straw; $3=$ calf legs are resting on top of straw.

\section{Feed Analysis}

Samples of CMR and starter grain were collected weekly, composited monthly on a wet weight basis, and analyzed at Dairyland Laboratories (St. Cloud, MN) using wet chemistry methods. Organic matter concentration of feed was calculated as the difference between DM content and ash content. Ash content was determined using method 942.05 of AOAC International (1996). Crude protein was determined using method 990.03 (AOAC International, 2000). Heat-stable, $\alpha$-amylase-treated and sodium sulfite NDF (aNDF) for feed ingredients was determined using an Ankom 200 fiber analyzer (Ankom Technology, Macedon, NY) based on procedures described by Van Soest et al., (1991). Ether extract was determined by method 920.39 (AOAC International, 2000). Concentrations of minerals in feed were determined by method 985.01 (AOAC International, 1995). Metabolizable energy intake was calculated using NRC (2001) software with inputs of individual calf birth body weight, ambient temperature at birth, and CMR and supplemental fat feeding rates.

To estimate total-tract DM digestibility (DMd) from d 50 to 52 , starter grain and a total of 3 fecal grab samples per calf (10 calves per treatment) were collected. Samples of starter grain were composited into one sample and individual calf fecal samples were composited (equal amount on a wet weight basis) into one sample per calf, dried at $60^{\circ} \mathrm{C}$ until static weight, and ground through a 1-mm screen in a Wiley mill (Arthur H. Thomas, Philadelphia, PA). Analysis of starter grain
Table 2. Fatty acid composition of milk replacer and fat supplement for calves fed 0,113 , or $227 \mathrm{~g} / \mathrm{d}$ of supplemental fat from d 2 to 21 of age

\begin{tabular}{lcc}
\hline $\begin{array}{l}\text { FA, } \\
\text { g/100 g of FA }\end{array}$ & $\begin{array}{c}\text { Milk } \\
\text { replacer }\end{array}$ & $\begin{array}{c}\text { Fat } \\
\text { supplement }\end{array}$ \\
\hline C10:0 & 0.14 & 0.02 \\
C12:0 & 0.1 & 0.3 \\
C13:0 & 0.56 & 0.12 \\
C14:0 & 1.6 & 3.0 \\
C15:0 & 0.28 & 0.20 \\
C16:0 & 24.6 & 25.4 \\
C16:1 & 3.0 & 3.0 \\
C17:0 & 0.49 & 0.49 \\
C17:1 & 0.28 & 0.30 \\
C18:0 & 12.9 & 12.6 \\
C18:1 & 44.4 & 42.2 \\
C18:2 & 10.2 & 9.8 \\
C18:3 & 0.28 & 0.16 \\
C20:0 & 0.14 & 0.20 \\
C20:1 & 1.13 & 1.27 \\
C20:2 & 0.07 & 0.10 \\
\hline
\end{tabular}

and fecal samples included DMd using acid-insoluble ash as an internal marker (Block et al., 1981).

Milk replacer was formulated to contain $28 \% \mathrm{CP}$ and $15 \%$ fat on an as-fed basis; actual analyzed $\mathrm{CP}$ and fat on a DM basis was 30.9 and $15.7 \%$, respectively (Table 1). Supplemental fat contained $7.7 \% \mathrm{CP}$ and $57.4 \%$ fat on a DM basis. Fat supplement contained $25.4 \%$ palmitic, $12.6 \%$ stearic, and $42.2 \%$ oleic acids (Table 2 ). Milk replacer and fat supplement contained marginal amounts of essential FA (Leplaix-Charlat et al., 1996; Hill et al., 2007).

\section{Body Growth and Health Monitoring}

Calves were weighed at birth and weekly thereafter each Friday at 0900 h. Body length (BL), heart girth (dairy calf weigh tape, Nasco, Fort Atkinson, WI), hip width, withers height (WH), and hip height (HH; measuring stick, Nasco) were also measured. Calculations of $\mathrm{ADG}$ of $\mathrm{BW}$ and stature were made from these measurements. Calves were observed at least twice daily from 1 to $56 \mathrm{~d}$ of age for general health, including appearance (alertness), and appetite (ability to consume feed). Fecal scores $[1=$ normal, firm, and well formed; 2 = semi-formed, pasty; $3=$ loose, but stays on top of bedding; and $4=$ watery, readily absorbed into bedding] were recorded daily from 1 to $56 \mathrm{~d}$ of age. Scours were defined as fecal score $\geq 3$. Scours were treated with oral electrolytes (Bounce Back, Manna Pro, Chesterfield, MO) and continued CMR feeding.

\section{Statistical Analysis}

Daily and weekly data were analyzed as a completely randomized design with 3 treatments using the PROC 
Table 3. Birth body weight (BBW), ambient temperature at birth, serum total protein, parity of dam, nesting score, fecal score, and weekly rectal temperature of dairy calves fed 0,113 , or $227 \mathrm{~g} / \mathrm{d}$ of supplemental fat from d 2 to 21 of age

\begin{tabular}{|c|c|c|c|c|c|c|c|}
\hline \multirow[b]{2}{*}{ Item } & \multicolumn{3}{|c|}{ Treatment $^{1}$} & \multirow[b]{2}{*}{ SEM } & \multicolumn{3}{|c|}{$P$-value } \\
\hline & $\mathrm{LF}$ & MF & $\mathrm{HF}$ & & Treatment & Linear & Quadratic \\
\hline $\mathrm{BBW}, \mathrm{kg}$ & 42.9 & 41.0 & 42.1 & 1.1 & 0.41 & - & - \\
\hline Ambient temperature at birth, ${ }^{\circ} \mathrm{C}$ & 5.5 & 5.3 & 5.0 & 1.1 & 0.82 & - & - \\
\hline Serum total protein. $\mathrm{mg} / \mathrm{dL}$ & 5.7 & 5.8 & 5.8 & 0.1 & 0.67 & - & - \\
\hline Parity of dam & 1.6 & 1.8 & 1.8 & 0.1 & 0.28 & - & - \\
\hline Rectal temperature, ${ }^{\circ} \mathrm{C}$ & 38.25 & 38.22 & 38.25 & 0.03 & 0.76 & 0.09 & 0.96 \\
\hline
\end{tabular}

${ }^{1}$ Preweaned calves were fed 1 of 3 treatments: (1) low fat [LF; 28\% CP, 15\% fat milk replacer (28:15 MR)]; (2) medium fat [(MF; 28:15 MR + $113 \mathrm{~g} / \mathrm{d}$ of commercial fat supplement (FS; $60 \%$ fat)]; (3) high fat [(HF); 28:15 MR $+227 \mathrm{~g} / \mathrm{d}$ FS]. The MF and HF calves received FS from d 1 to 21; all calves were fed LF from d 22 to 49 . Milk replacer was fed at $1.4 \%$ of BBW from d 1 to 10 , at $1.8 \%$ of BBW from d 11 to 42 , and at $0.9 \%$ of BBW from d 43 to 49 . Calves were weaned on d 49 and remained in hutches until d 56 .

MIXED procedure of SAS (release 9.2: SAS Institute Inc., Cary, NC). The final model included effects of birth weight, breed, sex, treatment, week, and interactions of treatment and week. Orthogonal linear and quadratic polynomials were constructed to test for differences among treatment means. Calf was considered a random effect. Initial serum total protein and BBW were used as covariates. Covariance structures considered for repeated-measures analysis were compound symmetry, autoregressive order 1, and unstructured covariance. The covariance structure that resulted in the Akaike information criterion closest to zero was used (Littell et al., 1996). Data measured over time were subjected to ANOVA by using the REPEATED statement in the MIXED procedure of SAS (Littell et al., 1996). Least squares means for treatment effects were separated by use of the PDIFF statement when the overall $F$-test was $P \leq 0.05$. Trends are indicated when $P \leq 0.10$. The largest SEM is reported.

\section{RESULTS}

\section{Calf Management}

Calf BBW averaged $42.0 \pm 1.1 \mathrm{~kg}$ and was similar among treatments $(P=0.41$; Table 3$)$. Calves were born over a 5-mo period (October through January) and average ambient temperature was below the LCT for a newborn calf, $5.3 \pm 1.1^{\circ} \mathrm{C}$ at birth, and was similar $(P=0.82)$ across treatments. We observed no effect of treatment on nesting score, fecal score, or weekly measures of rectal temperature (Table 3). Nesting score decreased $(P<0.001)$ over time as initial straw bedding became compacted with use. Consistently low fecal scores were observed during this study and were similar among treatments. Rectal temperature was similar $(P$ $=0.76)$ among treatments and tended $(P=0.09)$ to be highest in wk 3 with an average of $38.3 \pm 0.03^{\circ} \mathrm{C}$ (Table 3).

\section{Nutrient Intake}

Mean separation in starter intake was observed as early as d 14, but all calves were consuming a similar amount of starter grain by d 56 (Figure 1). Starter intake and starter intake expressed as a percentage of BW decreased (linear, $P<0.0001$ ) with FS on d 21, 42, and 49; however, we detected no FS effect by d 56 (Table 4; Figure 1). Peak starter intake was defined as the greatest amount of starter consumed per day during the 56-d preweaning phase. Starter intake peaked at $3.5,3.3$, and $3.2 \pm 0.1 \mathrm{~kg} / \mathrm{d}$ for $\mathrm{LF}, \mathrm{MF}$, and $\mathrm{HF}$, and tended $(P=0.09)$ to decrease linearly with increased FS (Table 4). As expected, starter intake increased $(P<$ 0.001 ) with increasing age (Figure 1$)$. Total DMI from d 3 to 49 was decreased (linear, $P=0.04$ ) by FS and tended to decrease (linear, $P=0.09$ ) with FS from d 3 to 56. Feed efficiency (gain:feed) through d 49 increased (linear, $P=0.01$ ) with FS as well as quadratically $(P$ $<0.02)$ as the increase in feed efficiency was similar between MF and HF (Table 4). Feed efficiency through d 56 , however, tended (linear, $P=0.08$ ) to decrease with HF. Day of age by which calves were consuming at least $250,500,1,000$, and $2,000 \mathrm{~g} / \mathrm{d}$ of starter grain intake was calculated to determine differences in the age by which calves consumed these amounts of starter. Calves fed LF consumed $250 \mathrm{~g} / \mathrm{d}$ of starter intake 5.5 and 6.4 $\pm 1.5 \mathrm{~d}$ earlier than MF and HF, respectively (Table 4). Supplemental fat increased (linear, $P=0.002$ ) the days to achieve $250,500,1,000$, and $2,000 \mathrm{~g} / \mathrm{d}$ of starter grain intake.

Calculated $\mathrm{ME}$ intake $\left(\mathbf{M E}_{\mathbf{I}}\right)$ from $\mathrm{CMR}$ was similar among treatments (Table 4). As expected, $\mathrm{ME}_{\mathrm{I}}$ increased (linear, $P<0.001$ ) with fat supplementation by 0.28 and $0.59 \pm 0.06 \mathrm{Mcal} / \mathrm{d}$ for $\mathrm{MF}$ and $\mathrm{HF}$ versus LF during the first $21 \mathrm{~d}$ in which fat was added to the CMR. Metabolizable energy intake was greater on wk 1 to 3 for HF compared with LF and MF (Figure 2). In wk $6, \mathrm{LF} \mathrm{ME}_{\mathrm{I}}$ was greater than $\mathrm{MF} \mathrm{ME}_{\mathrm{I}}$, and in wk 


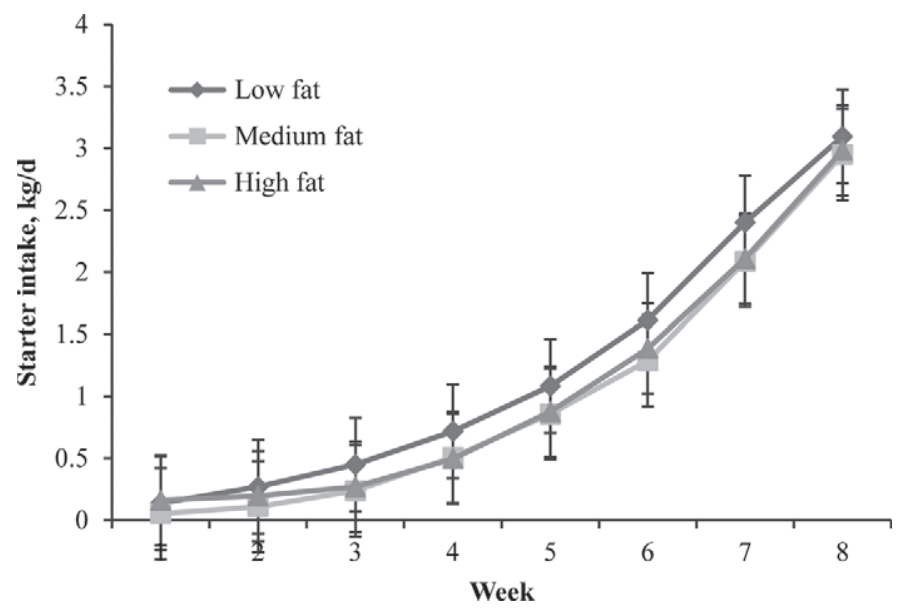

Figure 1. Starter intake during the first $56 \mathrm{~d}$ for calves fed milk replacer (MR) with 0,114 , or $227 \mathrm{~g} / \mathrm{d}$ supplemental fat during d 1-21 preweaning. Preweaned calves were fed 1 of 3 treatments: (1) low fat [LF; $28 \% \mathrm{CP}, 15 \%$ fat milk replacer (28:15 MR)]; (2) medium fat [(MF; $28: 15 \mathrm{MR}+113 \mathrm{~g} / \mathrm{d}$ of commercial fat supplement (FS; $60 \%$ fat)]; (3) high fat [(HF); 28:15 MR + $227 \mathrm{~g} / \mathrm{d}$ of FS]. The MF and HF calves received FS from d 1 to 21; all calves were fed LF from d 22 to 49. Milk replacer was fed at $1.4 \%$ of birth body weight (BBW) from d 1 to 10 , at $1.8 \%$ of $\mathrm{BBW}$ from d 11 to 42 , and at $0.9 \%$ of $\mathrm{BBW}$ from d 43 to 49. Calves were weaned on d 49 and remained in hutches until d 56. The largest SEM $=0.06$. Effects in model: treatment: $P=0.04$; week: $P<0.0001$; treatment $\times$ week: $P=0.42$.

7, LF $\mathrm{ME}_{\mathrm{I}}$ was greater than MF. Despite higher starter intake by LF, supply of $\mathrm{ME}_{\mathrm{I}}$ from calf starter did not differ $(P=0.18)$ among treatments. Because of greater starter intake by LF and higher energy intake through fat supplementation by $\mathrm{MF}$ and $\mathrm{HF}$, total $\mathrm{ME}_{\mathrm{I}}$ through $56 \mathrm{~d}$ was similar (linear, $P=0.31$ ) among treatments (Table 4).

During wk $1, \mathrm{ME}_{\mathrm{I}}$ increased (linear, $P<0.001$ ) with fat supplementation (Table 5). Metabolizable energy for maintenance was similar among treatments (Table 5). Intake above maintenance and energy allowable gain was increased (linear, $P<0.0001$ ) with FS. Efficiency of $\mathrm{BW}$ gain per unit of $\mathrm{ME}_{\mathrm{I}}$ was similar among treatments on $\mathrm{d} 7$ but decreased (linear; $P<0.002$ ) on d 21 and 42 by fat supplementation (Table 5 ). Intake of ME was greater in wk 1 for LF compared with MF, and $\mathrm{HF}$ was greater than LF and MF (treatment $x$ week: $P<0.001$; Figure 2). By wk 2 and $3, \mathrm{ME}_{\mathrm{I}}$ by $\mathrm{HF}$ was still greater than that by LF but similar to that by MF (treatment $\times$ week: $P<0.001$ ). Additionally, by wk 6 and 7, ME $\mathrm{I}_{\mathrm{I}}$ was greater for $\mathrm{LF}$ compared with $\mathrm{HF}$ (treatment $\times$ week: $P<0.001$; Figure 2 ).

Calculated intake of $\mathrm{CP}$ from $\mathrm{CMR}$ and starter grain from d 3 to 49 (linear, $P=0.21$; quadratic, $P=0.44$ ) and from d 3 to 56 (linear, $P=0.34$; quadratic, $P=$ 0.61 ) was similar among treatments; however, calculated total fat intake increased linearly $(P<0.0001)$ with increased amount of FS (Table 6). Intake of C16:0 and
C18:1 from CMR was similar among treatments. Intake of C16:0 from FS was 0.36 and $0.73 \mathrm{~kg}$ and intake of $\mathrm{C} 18: 1$ was 0.60 and $1.21 \mathrm{~kg}$ during the first $3 \mathrm{wk}$ for $\mathrm{MF}$ and HF, respectively. Total intake of both C16:0 and C18:1 from CMR and FS was increased (linear, $P<$ 0.0001 ) by fat supplementation. Postweaning measures of apparent total-tract DMd (\%) tended to increase (quadratic, $P=0.08$ ) for MF; however, apparent DMd $(\mathrm{kg} / \mathrm{d})$ was not affected by FS (Table 6).

\section{Growth and Structural Development}

Calves fed FS had greater BW gain during wk 1 (linear, $P<0.02$ ) and wk 2 (linear, $P<0.01$ ) than LF (Table 7). Very few calves lost weight during wk 1 (n = 6); however, of those losing weight during the first week, 4 were fed LF and 1 calf each were fed MF and HF. Body weight gain through $21 \mathrm{~d}$ increased (linear, $P<$ 0.004 ) with increased FS (Table 7). Average daily gain during wk 1 to 3 tended (treatment $\times$ week: $P=0.08$ ) to be greater for MF and HF compared with LF (Figure 3). We observed no differences in measures of $\mathrm{HH}$, WH, BL, heart girth, or hip width among treatments through d 21, although all measures were numerically decreased by FS. Differences in total gain and ADG observed in calves at $21 \mathrm{~d}$ were no longer apparent by 42 d. By 56 d, no differences in total BW gain were apparent among treatments; however, FS decreased HH gain (linear, $P<0.01$ ) and tended to decrease $\mathrm{WH}$ gain (linear, $P=0.09$ ) and BL gain (linear, $P=0.08$ ).

\section{DISCUSSION}

Mean ambient temperature, $5.3 \pm 1.1^{\circ} \mathrm{C}$, during this trial was greater than anticipated but still resulted in an average increased in ME requirements of approximately 0.56 Mcal of $\mathrm{NE}_{\mathrm{M}} / \mathrm{d}$ (NRC, 2001). Calculated as-fed protein:fat for treatments used in this study were 28:15, 26:20, and 24:25 for LF, MF, and HF, respectively. The optimal concentration of protein in milk replacer diets for young dairy calves is a function of feeding rate and energy supply (Blome et al., 2003; Bartlett et al., 2006). Deposition of body protein in the growing calf is a linear function of dietary protein intake and is largely unrelated to energy intake as long as sufficient energy is available for body protein deposition (Donnelly and Hutton, 1976; Bartlett et al., 2006). We hypothesized that supplemental energy from fat during cold stress would increase the energy available for protein deposition during the first $3 \mathrm{wk}$ after birth. The LF diet was similar in CP:ME to that fed by Tikofsky et al. (2001), which was reported to be deliver the optimum CP:ME ratio when calves were not fed starter grain before weaning and without attempting to balance dietary 


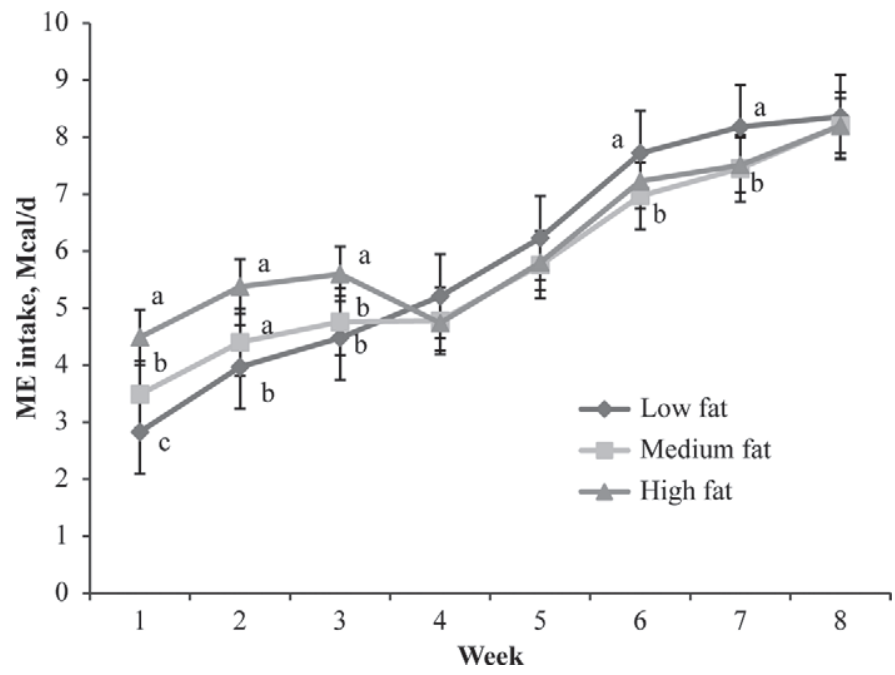

Figure 2. Metabolizable energy intake during the first $56 \mathrm{~d}$ for calves fed milk replacer with 0 (low), 114 (medium), or 227 (high) g/d of supplemental fat containing $60 \%$ fat on a DM basis. Treatment: $P$ $=0.33$; week: $P<0.001$; treatment $\times$ week: $P<0.001 .{ }^{\mathrm{a}-\mathrm{c}}$ Means with different letters indicate a significant difference at $P<0.05$.
AA. The LF treatment was also similar to the optimum when calves were fed starter grain and weaned using efforts to balance AA in the CMR (Hill et al., 2009a). The addition of supplemental fat to LF, during mild cold stress, may result in suboptimal CMR CP:ME.

\section{Starter and Nutrient Intakes and Feed Efficiency}

Lower starter intake by calves fed supplemental fat through d 49 is not surprising because these calves likely experienced greater satiety due to the amount and source of energy intake. By d 56, however, starter intake was similar across treatments. Previous work altering the fat content of MR did not decrease starter intake but linearly decreased digestibility of DM, OM, and fat (Hill et al., 2009b). Environmental temperatures during the work conducted by Hill et al. (2009b) were lower than those in the current trial and averaged $2^{\circ} \mathrm{C}$ and ranged from -10 to $20^{\circ} \mathrm{C}$.

Effects of supplemental fat in lowering the age at which calves consistently consumed targeted amounts of

Table 4. Mean intakes of calf milk replacer (CMR), starter grain, peak starter intake, starter intake expressed as a percentage of BW, total DMI, feed efficiency, and days of age in which calves were consuming selected amounts of starter intake

\begin{tabular}{|c|c|c|c|c|c|c|}
\hline \multirow[b]{2}{*}{ Item } & \multicolumn{3}{|c|}{ Treatment $^{1}$} & \multirow[b]{2}{*}{ SEM } & \multicolumn{2}{|c|}{$P$-value } \\
\hline & $\mathrm{LF}$ & $\mathrm{MF}$ & $\mathrm{HF}$ & & Linear & Quadratic \\
\hline $21 \mathrm{~d}$ & 0.4 & 0.2 & 0.1 & 0.04 & $<0.0001$ & 0.53 \\
\hline $42 \mathrm{~d}$ & 1.6 & 1.3 & 1.2 & 0.09 & 0.02 & 0.21 \\
\hline $49 \mathrm{~d}$ & 2.3 & 2.1 & 2.0 & 0.09 & 0.007 & 0.43 \\
\hline \multicolumn{7}{|l|}{ Starter intake, $\%$ of BW } \\
\hline $21 \mathrm{~d}$ & 0.7 & 0.4 & 0.3 & 0.07 & $<0.0001$ & 0.39 \\
\hline $42 \mathrm{~d}$ & 2.1 & 1.7 & 1.6 & 0.01 & 0.005 & 0.24 \\
\hline $49 \mathrm{~d}$ & 2.9 & 2.6 & 2.4 & 0.1 & 0.005 & 0.48 \\
\hline $56 \mathrm{~d}$ & 3.5 & 3.4 & 3.3 & 0.1 & 0.12 & 0.74 \\
\hline DMI, $\mathrm{kg}(\mathrm{d} 3-49)^{2}$ & 78.3 & 70.6 & 70.6 & 2.6 & 0.04 & 0.25 \\
\hline DMI, kg $(\mathrm{d} 3-56)^{2}$ & 97.8 & 90.8 & 90.5 & 3.1 & 0.09 & 0.39 \\
\hline Peak starter intake, $\mathrm{kg} / \mathrm{d}$ & 3.5 & 3.3 & 3.2 & 0.1 & 0.09 & 0.64 \\
\hline $1000 \mathrm{~g} / \mathrm{d}$ & 31.2 & 34.4 & 36.0 & 1.2 & 0.003 & 0.55 \\
\hline $2000 \mathrm{~g} / \mathrm{d}$ & 42.9 & 44.8 & 45.3 & 0.8 & 0.03 & 0.49 \\
\hline $\mathrm{ME}_{\mathrm{I}} \mathrm{CMR}, \mathrm{Mcal} / \mathrm{d}$ & 2.74 & 2.69 & 2.75 & 0.06 & 0.90 & 0.48 \\
\hline $\mathrm{ME}_{\mathrm{I}} \mathrm{fat}^{3}{ }^{3} \mathrm{Mcal} / \mathrm{d}$ & 0 & 0.28 & 0.59 & 0.04 & $<0.001$ & 0.98 \\
\hline $\mathrm{ME}_{\mathrm{J}} \mathrm{CSI}^{4}{ }^{4} \mathrm{Mcal} / \mathrm{d}$ & 3.16 & 2.74 & 2.84 & 0.2 & 0.18 & 0.28 \\
\hline Total $\mathrm{ME}_{\mathrm{I}},{ }^{5} \mathrm{Mcal} / \mathrm{d}$ & 5.87 & 5.73 & 6.11 & 0.2 & 0.31 & 0.26 \\
\hline
\end{tabular}

${ }^{1}$ Preweaned calves were fed 1 of 3 treatments: (1) low fat [LF; 28\% CP, 15\% fat milk replacer (28:15 MR)]; (2) medium fat [MF; 28:15 MR + $113 \mathrm{~g} / \mathrm{d}$ of commercial fat supplement (FS; $60 \%$ fat)]; (3) high fat[(HF); $28: 15 \mathrm{MR}+227 \mathrm{~g} / \mathrm{d}$ FS]. The MF and HF calves received FS from d 1 to 21; all calves were fed LF from d 22 to 49. Milk replacer was fed at 1.4\% of birth body weight (BBW) from d 1 to 10 , at 1.8\% of BBW from d 11 to 42 , and at $0.9 \%$ of BBW from d 43 to 49 . Calves were weaned on d 49 and remained in hutches until d 56.

${ }^{2} \mathrm{DMI}=($ starter intake + milk replacer DM + FS $)$.

${ }^{3}$ Metabolizable energy intake $\left(\mathrm{ME}_{\mathrm{I}}\right)$ from fat supplement.

${ }^{4} \mathrm{ME}_{\mathrm{I}}$ from calf starter intake.

${ }^{5}$ Total $(\mathrm{CMR}+$ fat + starter grain $) \mathrm{ME}_{\mathrm{I}}$ per day. 
Table 5. Least squares means for metabolizable energy intake $\left(\mathrm{ME}_{\mathrm{I}}\right)$, metabolizable energy for maintenance $\left(\mathrm{ME}_{\mathrm{M}}\right)$ at ambient temperature at birth, $\mathrm{ME}_{\mathrm{I}}$ above maintenance costs, and energy available for gain for calves fed increasing amounts of supplemental fat during mild cold stress

\begin{tabular}{|c|c|c|c|c|c|c|}
\hline \multirow[b]{2}{*}{ Item } & \multicolumn{3}{|c|}{ Treatment $^{1}$} & \multirow[b]{2}{*}{ SEM } & \multicolumn{2}{|c|}{$P$-value } \\
\hline & $\mathrm{LF}$ & MF & $\mathrm{HF}$ & & Linear & Quadratic \\
\hline \multicolumn{7}{|l|}{ Week 1} \\
\hline $\mathrm{ME}_{\mathrm{I}}{ }^{2}{ }^{2} \mathrm{Mcal} / \mathrm{d}$ & 2.72 & 3.31 & 4.11 & 0.08 & $<0.001$ & 0.32 \\
\hline $\mathrm{ME}_{\mathrm{M},}{ }^{3} \mathrm{Mcal} / \mathrm{d}$ & 2.17 & 2.11 & 2.14 & 0.02 & 0.23 & 0.19 \\
\hline $\mathrm{ME}_{\mathrm{I}}-\mathrm{ME}_{\mathrm{M}}, \mathrm{Mcal} / \mathrm{d}$ & 0.55 & 1.20 & 1.97 & 0.07 & $<0.001$ & 0.51 \\
\hline Energy-allowable $\mathrm{ADG},{ }^{3} \mathrm{~kg} / \mathrm{d}$ & 0.23 & 0.46 & 0.68 & 0.01 & $<0.001$ & 0.95 \\
\hline d 21 & 68.5 & 50.6 & 48.8 & 4.3 & 0.002 & 0.13 \\
\hline d 42 & 68.5 & 50.6 & 48.8 & 4.4 & 0.002 & 0.13 \\
\hline d 49 & 35.5 & 33.0 & 32.2 & 2.2 & 0.32 & 0.77 \\
\hline d 56 & 28.9 & 29.5 & 29.4 & 1.6 & 0.84 & 0.88 \\
\hline
\end{tabular}

${ }^{1}$ Preweaned calves were fed 1 of 3 treatments: (1) low fat [LF; $28 \%$ CP, $15 \%$ fat milk replacer $\left.(28: 15 \mathrm{MR})\right] ;(2)$ medium fat [MF; $28: 15 \mathrm{MR}+$ $113 \mathrm{~g} / \mathrm{d}$ of commercial fat supplement (FS; $60 \%$ fat)]; (3) high fat [(HF); $28: 15 \mathrm{MR}+227 \mathrm{~g} / \mathrm{d}$ FS]. The MF and HF calves received FS from d 1 to 21; all calves were fed LF from d 22 to 49 . Milk replacer was fed at 1.4\% of birth body weight (BBW) from d 1 to 10 , at $1.8 \%$ of BBW from d 11 to 42 , and at $0.9 \%$ of BBW from d 43 to 49 . Calves were weaned on d 49 and remained in hutches until d 56.

${ }^{2}$ Dietary energy density $\times$ DMI.

${ }^{3}$ Calculated using NRC (2001) software with inputs of BBW, ambient temperature at birth, and calf milk replacer and supplemental fat feeding rates.

$250,500,1,000$, and $2,000 \mathrm{~g} / \mathrm{d}$ starter grain is intriguing and warrants further investigation. Questions remain regarding the effect of reducing day of age to consume benchmark amounts of starter. Calves consuming appreciable amounts of starter at a younger age might have advantages in gastrointestinal tract maturation, greater capacity for nutrient absorption, and increased gut integrity (Hill et al., 2010; Sweeney et al., 2010). Although digestibility measurements were not collected during fat supplementation, postweaning measures of total-tract apparent DMd in this study were similar across all treatments. We anticipated that greater rumen development associated with greater amounts of starter intake by LF would result in greater DMd; however, greater starter intake and (likely) increased rates of passage of digesta resulted in similar DMd among treatments. Apparent DM, OM, NDF, CP, and gross energy digestibility were greater in control-fed calves compared with calves fed a higher plane of nutrition 1 wk after weaning (Terré and Bach, 2007).

Greater feed efficiency for fat-supplemented calves is not surprising, given the greater $\mathrm{ME}_{\mathrm{I}}$ and higher coeffi-

Table 6. Least squares means of calculated intakes of CP, fat, ME, and apparent total-tract nutrient digestibility from d 2 through d 49 for calves fed increasing amounts of supplemental fat during mild cold stress

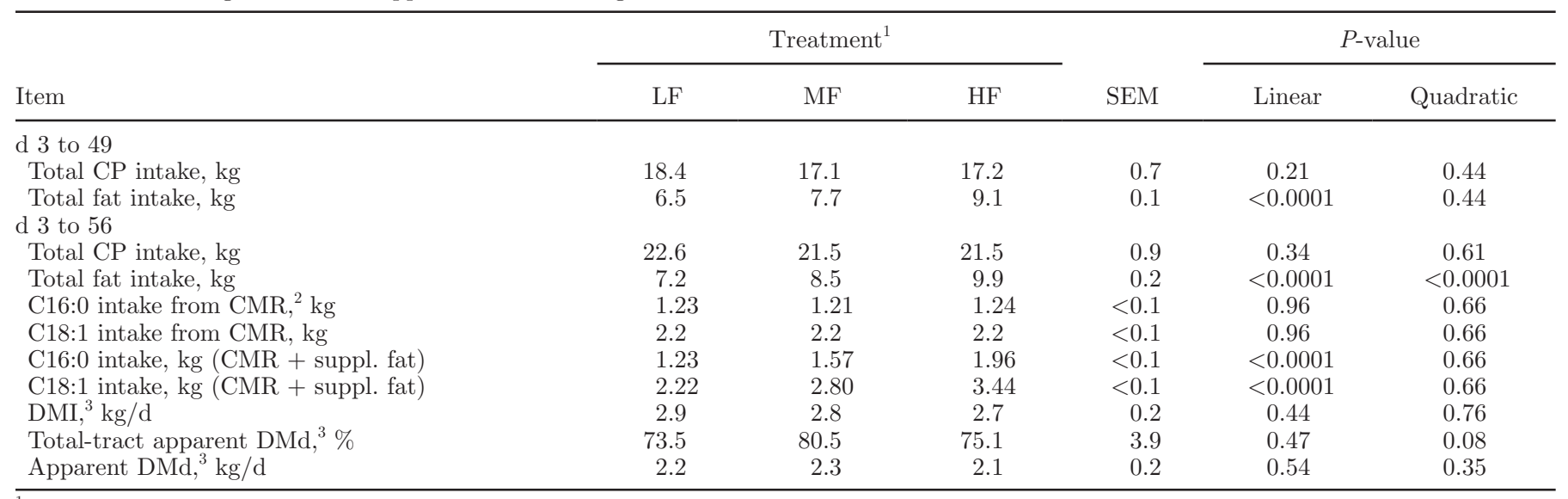

${ }^{1}$ Preweaned calves were fed 1 of 3 treatments: (1) low fat [LF; $28 \%$ CP, $15 \%$ fat milk replacer (28:15 MR)]; (2) medium fat [MF; 28:15 MR + $113 \mathrm{~g} / \mathrm{d}$ of commercial fat supplement (FS; $60 \%$ fat)]; (3) high fat [(HF); $28: 15 \mathrm{MR}+227 \mathrm{~g} / \mathrm{d}$ FS]. The MF and HF calves received FS from d 1 to 21; all calves were fed LF from d 22 to 49. Milk replacer was fed at $1.4 \%$ of birth body weight (BBW) from d 1 to 10 , at $1.8 \%$ of BBW from d 11 to 42 , and at $0.9 \%$ of BBW from d 43 to 49 . Calves were weaned on d 49 and remained in hutches until d 56.

${ }^{2} \mathrm{CMR}=$ calf milk replacer.

${ }^{3} \mathrm{DMI}$ and DM digestibility (DMd) measured on (d 50 to 52 ). 
Table 7. Least squares means for BW and body measurements during the supplemental fat feeding period (1 to $21 \mathrm{~d})$, at the start of weaning $(42 \mathrm{~d})$ and at the end of the trial ( $56 \mathrm{~d})$ for calves fed increasing amounts of supplemental fat during mild cold stress

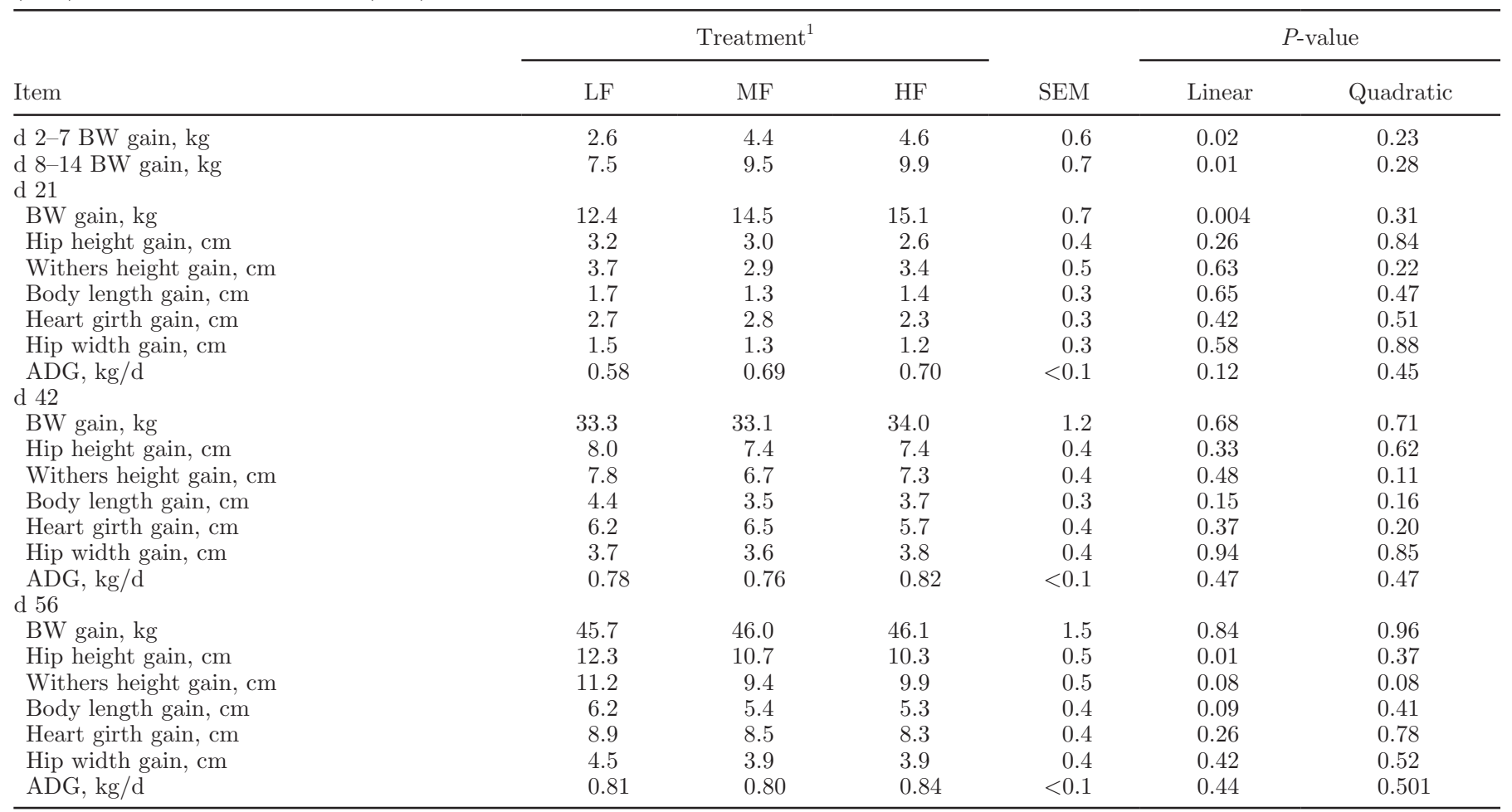

${ }^{1}$ Preweaned calves were fed 1 of 3 treatments: (1) low fat [LF; 28\% CP, 15\% fat milk replacer (28:15 MR)]; (2) medium fat [(MF; 28:15 MR + $113 \mathrm{~g} / \mathrm{d}$ of commercial fat supplement (FS; 60\% fat)]; (3) high fat [(HF); 28:15 MR + $227 \mathrm{~g} / \mathrm{d}$ FS]. The MF and HF calves received FS from d 1 to 21 ; all calves were fed LF from d 22 to 49 . Milk replacer was fed at $1.4 \%$ of birth body weight (BBW) from d 1 to 10 , at $1.8 \%$ of BBW from d 11 to 42 , and at $0.9 \%$ of BBW from d 43 to 49 . Calves were weaned on d 49 and remained in hutches until d 56 .

cient of digestibility for supplemental fat versus starter grain. Supplementing whole milk or milk replacer with $113 \mathrm{~g} / \mathrm{d}$ of supplemental fat increased BW gain during the first month of life (Jaster et al., 1990).

\section{FA Intake and Growth}

Supplemental fat increased intakes of $\mathrm{C} 16: 0$ and C18:0. In preruminant calves, high-fat diets stimulate secretion of triglyceride-rich lipoproteins such as chylomicrons and very low density lipoproteins (Piot et al., 2000). Metabolism of FA and their subsequent mitochondrial oxidation depends on coordinated induction of enzymes activities involved in FA metabolism at both the extra-mitochondrial level (FA uptake) and the mitochondrial level (flux of FA through $\beta$-oxidation), and some of these steps have been shown to be regulated by dietary FA (Piot et al., 2000). In addition to serving as an energy source, FA are biologically active molecules that can regulate gene expression, enzyme activities, binding proteins, and other cellular processes. Hepatocytes from 7- to 10-d-old calves exposed to $2 \mathrm{~m} M$ palmitic acid or to $1 \mathrm{~m} M$ palmitic acid plus $1 \mathrm{~m} M$ stearic acid had greater rates of oxidation and ketogenesis of FA compared with all other treatments, which included PUFA (Mashek and Grummer, 2003). In neonates, the capacity for FA oxidation rapidly increases after birth to meet energy demands (Girard et al., 1992; Odle et al., 1995; Oden and Treen, 2003). Supplying greater amounts of FA during the early preweaning period could stimulate increased capacity for FA oxidation and alter gene expression toward oxidation and away from esterification, perhaps ultimately altering body composition.

\section{Energy Intake Above Maintenance}

The lower border of the zone of thermoneutrality is called the lower critical temperature, LCT, below which the animal must increase its rate of heat production to maintain homeothermy. The level of nutrient intake likely has a marked effect on calf body heat production and consequently on LCT. One objective of feeding supplemental fat is to increase energy intake during the first weeks of age when starter intake is expected to be low and not making a substantial contribution toward meeting energy requirements for maintenance and growth. Net energy intake above maintenance was 


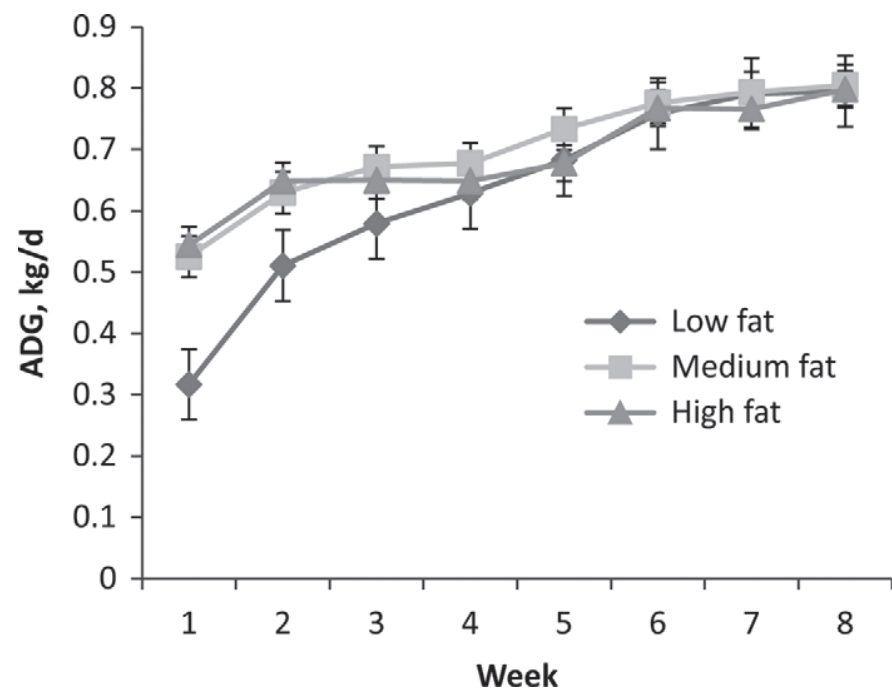

Figure 3. Least squares means for weekly ADG of calves fed 1 of 3 treatments: (1) low fat [LF; $28 \%$ CP, $15 \%$ fat milk replacer $(28: 15$ MR)]; (2) medium fat [(MF; $28: 15 \mathrm{MR}+113 \mathrm{~g} / \mathrm{d}$ of commercial fat supplement (FS; $60 \%$ fat)]; (3) high fat [(HF); $28: 15 \mathrm{MR}+227 \mathrm{~g} / \mathrm{d}$ of FS]. The MF and HF calves received FS from d 1 to 21; all calves were fed LF from d 22 to 49 . Milk replacer was fed at $1.4 \%$ of birth body weight (BBW) from d 1 to 10 , at $1.8 \%$ of BBW from d 11 to 42 , and at $0.9 \%$ of BBW from d 43 to 49 . Calves were weaned on d 49 and remained in hutches until d 56. Largest SEM $=0.08$. Effects in model: treatment: $P=0.43$; week: $P<0.0001$; treatment $\times$ week: $P=0.08$.

increased with FS on d 7 and 21, allowing calves to nearly double birth BW during the first week, resulting in differences between control and fat-supplemented calves. Additionally, research reports investigating the importance of modulating the diet to prevent cold stress in preweaned pigs has shown a clear effect of nutrient use for growth and immune system function (Salak-Johnson and McGlone, 2007).

\section{DM Digestibility}

Work described by Young (1981) indicated that cold stress was associated with increased resting metabolic rate, increased energy requirement for maintenance, and stimulation of appetite, resulting in an increased rate of passage of digesta and a decrease in digestive efficiency. As a result, cold-stressed calves should consume more starter grain but have a lower efficiency of growth. The net effect of cold stress should be a decrease in efficiency of growth due to a decrease in efficiency of use of dietary energy. We hypothesized that calves fed supplemental fat would have lower apparent total-tract starter digestibility in MF and HF compared with LF because of a less developed rumen at weaning. Development and function of pregastric fermentation was not measured in this study.

\section{Growth and Structural Development}

Differences in starter intake likely explain the lack of difference in BW gain among treatments before weaning and at the end of the trial. By d 56, reduced $\mathrm{HH}$ gain and tendencies toward decreased $\mathrm{WH}$ and $\mathrm{BL}$ gain might indicate that supplemental fat decreased muscle or bone growth, or both.

\section{Effects of Shifts in Nutrient Supply}

During trial planning, we discussed the potential effect of an abrupt decrease in dietary energy when supplemental fat was discontinued after wk 3 on calf health (Hickey et al., 2003) and growth. Calves fed HF experienced a significant decrease in $\mathrm{ME}_{\mathrm{I}}$ between wk 3 and 4, whereas $\mathrm{ME}_{\mathrm{I}}$ in $\mathrm{MF}$ calves plateaued between wk 3 and 4 . This is in contrast to the steady increase in $\mathrm{ME}_{\mathrm{I}}$ by LF calves. Perhaps a gradual decrease in supplemental fat feeding during the second or third week of the trial might have resulted in a more gradual changeover to consuming more starter grain, especially for $\mathrm{HF}$ calves.

\section{CONCLUSIONS}

Supplemental fat fed during the first 3 wk of the preweaned phase during mild cold stress increased energy intake and ADG but reduced starter intake until weaning. Starter intake by LF calves was greatest until the beginning of weaning, after which starter intake was similar among treatments. Because of the greater starter intake, total $\mathrm{ME}_{\mathrm{I}}$ was similar among treatments. Feed efficiency through d 49 was greater for calves fed supplemental fat. Average daily gain during fat supplementation was greater for MF and HF than for LF. Lack of increase in BW gain and feed efficiency between MF and $\mathrm{HF}$ treatments indicated that $\mathrm{HF}$ did not result in advantages over MF. By d 56, gain in $\mathrm{HH}$ was reduced and gain in $\mathrm{WH}$ and $\mathrm{BL}$ tended to be decreased by FS. During supplemental fat feeding, fat reduced the efficiency of BW gain per unit of energy intake. The addition of FS to LF, during mild cold stress, may result in suboptimal CMR CP:ME. Future research should investigate slower removal of supplemental fat from the milk replacer to prevent large changes in energy intake.

\section{ACKNOWLEDGMENTS}

This study was supported in part by funds from State of Minnesota and USDA-CSREES appropriated to the Minnesota Agricultural Experiment Station.

\section{REFERENCES}

AOAC International. 1995. Official Methods of Analysis. 16th ed. AOAC International, Arlington, VA. 
AOAC International. 1996. Official Methods of Analysis. 16th ed. AOAC International, Arlington. VA.

AOAC International. 2000. Official Methods of Analysis. 17th ed. AOAC International, Arlington, VA.

Bar-Peled, U., B. Robinzon, E. Maltz, H. Tagari, Y. Folman, I. Bruckental, H. Voet, H. Gacitua, and A. R. Lehrer. 1997. Increased weight gain and effects on production parameters of Holstein heifer calves that were allowed to suckle from birth to six weeks of age. J. Dairy Sci. 80:2523-2528.

Bartlett, K. S., F. K. McKeith, M. J. VandeHaar, G. E. Dahl, and J. K. Drackley. 2006. Growth and body composition of dairy calves fed milk replacers containing different amounts of protein at two feeding rates. J. Anim. Sci. 84:1454-1467.

Bascom, S. A., R. E. James, M. L. McGilliard, and M. Van Amburgh. 2007. Influence of dietary fat and protein on body composition of Jersey bull calves. J. Dairy Sci. 90:5600-5609.

Bernal-Santos, G., J. W. Perfield 2nd, D. M. Barbano, D. E. Bauman, and T. R. Overton. 2003. Production responses of dairy cows to dietary supplementation with conjugated linoleic acid (CLA) during the transition period and early lactation. J. Dairy Sci. 86:3218-3228.

Block, E., L. H. Kilmer, and L. D. Muller. 1981. Acid insoluble ash as a marker of digestibility for sheep fed corn plants or hay for lactating dairy cattle fed hay ad libitum. J. Anim. Sci. 52:1164-1169.

Blome, R. M., J. K. Drackley, F. K. McKeith, M. F. Hutjens, and G. C. McCoy. 2003. Growth, nutrient utilization, and body composition of diary calves fed milk replacers containing different amounts of protein. J. Anim. Sci. 81:1641-1655.

Curtis, S. E. 1974. Responses of the piglet to perinatal stressors. J. Anim. Sci. 38:1031-1036.

Donnelly, P. E., and J. B. Hutton. 1976. Effects of dietary protein and energy on growth of Friesian bull calves. 1. Food intake, growth and protein requirements. N. Z. J. Agric. Res. 19:289-297.

Girard, J., P. Ferré, J. P. Pégorier, and P. H. Duée. 1992. Adaptations of glucose and fatty acid metabolism during perinatal period and suckling-weaning transition. Physiol. Rev. 72:507-562.

Hickey, M. C., M. Drennan, and B. Earley. 2003. The effect of abrupt weaning of suckler calves on the plasma concentrations of cortisol, catecholamine, leukocytes, acute-phase proteins, and in vitro interferon-gamma production. J. Anim. Sci. 81:2847-2855.

Hill, S. R., K. F. Knowlton, K. M. Daniels, R. E. James, R. E. Pearson, A. V. Capuco, and R. M. Akers. 2008. Effects of milk replacer composition on growth, body composition, and nutrient excretion in preweaned Holstein heifers. J. Dairy Sci. 91:3145-3155.

Hill, T. M., J. M. Aldrich, R. L. Schlotterbeck, and H. G. Bateman II.. 2007. Effects of changing the fat and fatty acid composition of milk replacers fed to neonatal calves. Prof. Anim. Sci. 23:135-143.

Hill, T. M., H. G. Bateman II, J. M. Aldrich, and R. L. Schlotterbeck. 2009a. Optimizing nutrient ratios in milk replacers for cavles less than five weeks of age. J. Dairy Sci. 92:3281-3291.

Hill, T. M., H. G. Bateman II, J. M. Aldrich, and R. L. Schlotterbeck. 2009b. Effects of fat concentration of a high-protein milk replacer on calf performance. J. Dairy Sci. 92:5147-5153.

Hill, T. M., H. G. Bateman, J. M. Aldrich, and R. L. Schlotterbeck. 2010. Effect of milk replacer program on digestion of nutrients in dairy calves. J. Dairy Sci. 93:1105-1115.

Jasper, J., and D. M. Weary. 2002. Effects of ad libitum milk intake on dairy calves. J. Dairy Sci. 85:3054-3058.

Jaster, E. H., G. C. McCoy, and R. L. Fernando. 1990. Dietary fat in milk replacers for dairy calves raised in hutches during winter. J. Dairy Sci. 73:1843-1850.

Jaster, E. H., G. C. McCoy, N. Spanski, and T. Tomkins. 1992. Effect of extra energy as fat or milk replacer solids in diets of young calves on growth during cold weather. J. Dairy Sci. 75:2524-2531.

Jenkins, K. J., J. K. Kramer, F. D. Sauer, and D. B. Emmons. 1985. Influence of triglycerides and free fatty acids in milk replacers on calf performance, blood plasma, and adipose lipids. J. Dairy Sci. 68:669-680.

Khan, M. A., J. J. Lee, W. S. Lee, H. S. Kim, K. S. Ki, T. Y. Hur, G. H. Suh, S. J. Kang, and Y. J. Choi. 2007. Structural growth, rumen development, and metabolic and immune responses of Holstein male calves fed milk through step-down and conventional methods. J. Dairy Sci. 90:3376-3387.

Khan, M. A., D. M. Weary, and M. A. G. von Keyserlingk. 2011. Invited review: Effects of milk ration on solid feed intake, weaning, and performance in dairy heifers. J. Dairy Sci. 94:1071-1081.

Leplaix-Charlat, L., D. Bauchart, D. Durand, P. M. Laplaud, and M. J. Chapman. 1996. Plasma lipoproteins in preruminant calves fed diets containing tallow or soybean oil with and without cholesterol. J. Dairy Sci. 79:1267-1277.

Littell, R. C., G. A. Milliken, W. W. Stroup, and R. D. Wolfinger. 1996. SAS System of Mixed Models. SAS Institute Inc., Cary, NC.

Mashek, D. G., and R. R. Grummer. 2003. Effects of long chain fatty acids on lipid and glucose metabolism in monolayer cultures of bovine hepatocytes. J. Dairy Sci. 86:2390-2396.

Mills, J. K., D. A. Ross, and M. E. Van Amburgh. 2010. The effects of feeding medium-chain triglycerides on the growth, insulin responsiveness, and body composition of Holstein calves from birth to 85 $\mathrm{kg}$ of body weight. J. Dairy Sci. 93:4262-4273.

Nonnecke, B. J., M. R. Foote, J. M. Smith, B. A. Pesch, and M. E. Van Amburgh. 2003. Composition and functional capacity of blood mononuclear leukocyte populations from neonatal calves on standard and intensified milk replacer diets. J. Dairy Sci. 86:3592-3604.

NRC. 2001. Nutrient Requirements of Dairy Cattle. Natl. Acad. Press, Washington, DC.

Oden, J., and W. R. Treen. 2003. Inborn errors of fasting adaptation. Pages 591-608 in Nutrition in Pediatrics. W. A. Walker, J. B. Wakins, and C. Duggan, ed. B. C. Decker Inc., London, UK.

Odle, J., X. Lin, T. A. Van Kempen, J. K. Drackley, and S. H. Adams. 1995. Carnitine palmitoyltransferase modulation of hepatic fatty acid metabolism and radio-HPLC evidence for low ketogenesis in the neonatal pig. J. Nutr. 125:2541-2549.

Piot, C., J. Hocquette, P. Herpin, J. H. Veerkamp, and D. Bauchart. 2000. Dietary coconut oil affects more lipoprotein lipase activity than the mitochondria oxidative capacities in muscles of preruminant calves. J. Nutr. Biochem. 11:231-238.

Piot, C., J. F. Hocquette, J. H. Veerkamp, D. Durand, and D. Bauchart. 1999. Effects of dietary coconut oil on fatty acid oxidation capacity of the liver, the heart and skeletal muscles in the preruminant calf. Br. J. Nutr. 82:299-308.

Salak-Johnson, J. L., and J. J. McGlone. 2007. Making sense of apparently conflicting data: Stress and immunity in swine and cattle. J. Anim. Sci. 85(E-Suppl.):E81-E88.

Sweeney, B. C., J. P. Rushen, D. M. Weary, and A. M. B. de Passillé. 2010. Duration of weaning, starter intake and weight gain of dairy calves fed large amounts of milk. J. Dairy Sci. 93:148-152.

Terré, M. M. D., and A. Bach. 2007. Effect of level of milk replacer fed to Holstein calves on performance during the preweaning period and starter digestibility at weaning. Livest. Sci. 110:82-88.

Tikofsky, J. N., M. E. Van Amburgh, and D. A. Ross. 2001. Effect of varying carbohydrate and fat content of milk replacer on body composition of Holstein bull calves. J. Anim. Sci. 79:2260-2267.

van den Borne, J. J., G. E. Lobley, M. W. A. Verstegen, J. M. Muijlaert, S. J. J. Alferink, and W. J. J. Gerrits. 2007. Body fat deposition does not originate from carbohydrates in milk-fed calves. J. Nutr. 137:2234-2241.

Van Soest, P. J., J. B. Robertson, and B. A. Lewis. 1991. Methods for dietary fiber, neutral detergent fiber, and nonstarch polysaccharides in relation to animal nutrition. J. Dairy Sci. 74:3583-3597.

Young, B. A. 1981. Cold stress as it affects animal production. J. Anim. Sci. 52:154-163. 